\title{
Anti-Political Experiences of Women in Local Politics in Turkey: An Arendtian Perspective
}

\author{
Senem Yıldırım
}

Ipek University, Turkey

\section{Doi:10.5901/ajis.2013.v2n8p535}

\begin{abstract}
The question of "What is political?" is a problematization of drawing boundaries. In Arendt's theory, the dichotomy of public versus private is important, as it draws the limits of what political is. In the mainstream reading of Arendt, political is essentially situated in the public sphere. The political could not survive within the confines of the private that hosts necessity and the concerns of the household. The one who is not free of necessity and concerns of the family could not act, i.e. could not become truly political in Arendtian sense. This paper employs this Arendtian conception of being political to question the 'political' experiences of women in local politics in Turkey. I argue that women in Turkish local politics are not involved decision making process and do not act in an Arendtian sense as they could never be free. Their "political" experiences are confined within the limits of the private sphere as they could only "act" within the contexts that affirm traditional gender roles of women, and even in their own discourses motherhood has the ultimate priority.
\end{abstract}

\section{Introduction}

Asking "What is political?" is not just a conceptualization effort, but also it is related with problematization of drawing boundaries. Assigning a political character to a specific phenomenon is essentially related with situating that phenomenon within the confines of a specific sphere.

This paper basically questions the political character of the experiences of women in local politics in Turkey. The political theory of Hannah Arendt is employed as the theoretical perspective, because when it comes to drawing limits and conceptualization of the eminent concepts of political theory, Arendt is among the outstanding figures of the $20^{\text {th }}$ century. Her way of thinking has a dichotomous character and one of the most important dichotomies in her theory is the binary opposition between the public and the private spheres. This dichotomy is vital, as it draws the limits of what political is. In the mainstream reading of Arendt, political is essentially situated in the public sphere, which is basically substantiated by the concepts of action, plurality, equality, exclusion of necessity, freedom and reality. The political could not survive within the confines of the private, which hosts necessity and the concerns of the household. The one who is not free of sheer necessity and concerns of the family could not act, i.e. could not become truly political in Arendtian sense.

By using this perspective, I argue that the data of TUBITAK (The Scientific and Technological Research Council of Turkey) funded project (109K182) conducted by Prof. Cindoglu (2011) and her research team ${ }^{1}$, named "Gender in Local Politics: Women's Representation at the Local Level", shows that women in local politics are not involved decision making process and do not act politically as they could never be free in an Arendtian sense. Their "political" experiences are confined within the limits of the private sphere as they could only "act" within the contexts that affirm traditional gender roles of women, and even in their own discourses motherhood has the ultimate priority.

Within this framework, firstly, Arendt's theoretical insights about the political and its relation to public versus the private dichotomy will be presented. After introducing the theoretical framework, basic information about the project in terms of its aim, methodology and duration will be stated. In the last part, quotations from the in-depth interviews done with the participants will be given in order to analyze the political nature of the experiences of women in local politics in Turkey. 


\section{Being Political: An Arendtian Perspective}

Arendt's conceptualization of the prominent concepts of political theory is not a repetition of well-known discussions in the field of political theory. In fact, it is more related with providing new and different perspective to the concepts like freedom, revolution, power, action, the political, the public etc. In The Human Condition $(1958$, p. 5) she simply invites us to think what we are doing. This call is important, as she states in The Origins of Totalitarianism (1966) and Eichmann in Jerusalem (1976), in the face of modern phenomenon of totalitarianism we could not use our already existing conceptual tools to think. They are useless. In order to understand this modern phenomenon we need new ones. Even though she never presents herself as the one who would provide these new tools for us, I think Arendt's is a priceless endeavor. To think about these important concepts again, suggesting new perspectives for the substantiation of these concepts are at the core of the very same endeavor.

The originality of her way of thinking is beyond doubt. Dichotomous character is an important part of this originality. By dichotomous character I mean that she is using binary oppositions while she is substantiating the concepts. For instance, the distinction between the public and private realms corresponds to the distinction between the political and the household (Arendt 1958, p.28). Along with the same lines, this binary opposition corresponds to dichotomies of freedom versus necessity; permanence versus futility; honor versus shame, respectively. (Arendt 1958, 73). Substantiating the concepts by using binary oppositions is also related to "mutual interdefinition" in her methodology (Dossa, 1989, p. 74). Arendt defines concepts through referring to other complementary concepts in her political theory. For instance, she makes a clear connection between the concepts of freedom, action, the public sphere and the political in her essay, "What is Freedom?" (1993). She argues that attainment of freedom is the raison d'etre for politics. The activity that assign political characteristic is action and action takes place within the public realm, in which plurality of human beings interact and perform (Arendt, 1993, pp. 146, 149). In her own words, "there is ... no real political substance. Politics arises in what lies between men and is established as relationships." (2005, p. 95).

As it is indicated, among these binary oppositions and interplay between concepts, the public versus the private is the most important one as it draws the boundaries of what is political and what is not. This spacial distinction in Arendt determines the political characteristic of a specific phenomenon. As the political essentially belongs to the public sphere, what belongs to the private sphere is non-political or sometimes you can call it anti-political. (Arendt, 1958, p. 54) As these two spheres are negating each other, the activities that take place within the confines of them respectively are mutually exclusive in terms of their nature. In order to understand this relationship it is vital to look into how Arendt substantiates each sphere respectively.

\section{The Public versus the Private}

While conceptualizing the public and the private Arendt turns to Athenian political life, in which two orders of existence, idion (man's own) and koinon (communal), are strictly separated. According to Greek thought, oikia (home) and the family belongs to the private sphere that is excluded from the public as well as the political. (Arendt, 1958, p. 24). The notions of necessity and usefulness that are essentially private do not belong to the realm of activities of action (praxis) and speech (lexis) that are essentially political (Arendt, 1958, p. 25). In her own words "the private realm of the household was the sphere where the necessities of life, of individual survival as well as of continuity of species were taken care of and guaranteed" (Arendt, 1958, p. 45). In order to be political you have to act; and action could be defined as "finding the right words at the right moment". In this context of the Greek polis, people are political as long as they decide everything through words and persuasion (speech) and they should exclude force and violence from their engagement (Arendt, 1958, p. 26). This is an agonistic notion of the public sphere, in which everyone distinguishes himself from others by showing his unique deeds and achievements (Arendt, 1958, p. 41). According to her, everything that takes place within the confines of the public sphere can be seen and heard by others. That is exactly what constitutes reality (Arendt 1958, p. 50). At this point, the public signifies a world that is common to all of us (Arendt 1958, p. 52). In direct opposition to this definition, being private is pointed out as being deprived of seeing and hearing others and of being seen and heard by them (Arendt, 1958, p. 58). To be private is to be alone and therefore without external verification of one's own reality. It is to be deprived of truly human life, objective relationships, and any achievement of permanence.

Some argues that Arendt's insistence on keeping such a strict distinction between those two spheres is related with her critique of liberalism. According to Zaretsky (1997, p. 212), liberalism valorized the private and prioritizes the protection of economics, family and religion from any interference on the side of the state. In opposition to that, Arendt supports an earlier tradition that prioritizes the public sphere of equality and representation over the private sphere of 
inequality and coercion. Therefore, being political corresponds to fulfill one's human potential. This is why the political has a central place in Arendt's political theory. However, her way of conceptualizing the political is not free from criticism. In the traditional reading of Arendtian political theory, Arendt's conception of politics seems to have an exclusivist character, because it precludes any private interests and social issues of the modern age. ${ }^{2}$ Even though they are valid to some extent, these kinds of critiques could stem from monolithic reading of the political in Arendt's theory. In order to avoid from a narrow reading and understand what political means in Arendt one should point out the multidimensional character of the political. Multi-dimensional character refers to different levels of a thorough reading: how the concept of the political is substantiated by other concepts such as action in Arendt's theory; what the specific conditions are for the political to emerge; and as a dynamic concept, what the political constitutes. Looking into these elements would provide us a comprehensive context to understand the concept of the political in Arendt.

\section{The Political}

I mainly argue that the concept of political in Arendt is not a monolithic and given concept. It has many dimensions. One reason behind this argument is the fact that there is a complex interplay of different concepts resulting from the mentioned interdefinitionality. The concept of the political is substantiated by different key concepts of Arendt's political theory such as action, plurality, equality, exclusion of necessity, freedom, reality, and the public space. In a nut shell, what makes people (who are free and equal citizens) political and meaningful is their capacity and ability to act in terms of performing and to disclose these actions in the form of speech within the confines of the public sphere. These people are acting in the existence of plurality of others and this public characteristic is what creates the reality. Because of this connectedness of the concepts, I argue that in order to understand what political is, firstly we need to look into how the very same concept is substantiated by others.

While making a thorough reading of the political one should begin with action. It is the activity that assigns the political character to a certain phenomenon. Within the moment of acting the individual becomes political. According to Arendt, the political sphere of affairs rises out of acting together (1958, p. 198). Action establishes boundless relationships that inherent new possibilities (1958, p. 190).

Moreover, there are some conditions for the political to emerge. The first condition is plurality. Arendt says that "[p]olitics is based on the fact of human plurality." (2005, p. 93). In The Human Condition where she presents the constituting activities of vita activa she indicates that human condition for action is plurality and action creates power just in the condition of plurality (Arendt, 1958, p. 7) At this point, we are talking about the plurality of people and perspectives as the political could only be engaged in the public between equal citizens. This would bring us another important condition that is equality. This concept of equality in Arendt has nothing to do with social or economic equality, but it is related with equality of political rank of the participants as citizens. In her own words equality means "to live among and to have to deal only with one's peers..." (Arendt, 1958, p.32) When it comes to equality you need "the other". To put it differently, you need the existence of "unequals", who are outside the realm of equals. You can find these "unequals" in their proper places in the context of the public versus the private dichotomy. Arendt argues that the household and the concepts of life and sheer necessity are at the center of "the strictest inequality". Men can only be equal as citizens when they step out from their home and enter the public sphere of their peers. Within these lines, exclusion of private household life from the political life becomes condition for the political to be actualized.

The political in Arendt is also a constitutive phenomenon. We can understand this by looking into what it constitutes. Firstly, the political constitutes the condition of being free. As it is mentioned, freedom could be attained and experienced among acting plurality of equals. To begin something anew, to take initiative among equals, to set something into motion, i.e. to act, is the only way for us to be free. Moreover, reality is constructed at the moment of acting. Arendt (1958, p. 208) argues that "without a space of appearance and without trusting in action and speech as a mode of being together, neither the reality one's self, of one's identity, nor the reality of the surrounding world can be established beyond doubt." The last constituted element is the public sphere. Arendt says that " the political realm rises directly out of acting together, the "sharing of words and deeds". Thus, action not only has the most intimate relationship to the public part of the world common to us all, but is the one activity which constitutes it." (Arendt, 1958, p. 198)

These conceptual elements that substantiate the concept of the political would be important for us to analyze any kind of experience and activity in terms of its nature and characteristic. In the second part of the paper I try to analyze the 
experiences of women in local politics in Turkey by referring to the data of project in question. By looking into their personal experiences, I try to analyze whether their experience in local politics is a political one or not in Arendtian sense. At this point, one could argue that using Arendt as theoretical reference in the context of gender would make no sense as Arendt's works are usually thought as gender-blind. The reason behind this criticism is the fact that Arendt mainly talks about the political in the city state, so she is basically talks about the experiences of free Athenian male citizens. Being a woman is doomed to being a part of the private sphere as women and slaves do not have any political rights in that specific context. With regard to this, I share the same idea with Bonie Honig. Honig (1995, p. 136) argues that we could not ignore Arendt's insightful analysis of agonistic and performative politics. It could be a good source for feminist theory. Even though Arendt's insistence of keeping the distinction between the public and the private intact, saving her conceptualization of the political from the context of polis would provide us a fresh outlook of the political experience in contemporary world. This paper is an attempt to provide the mentioned fresh perspective to a contemporary political experience in the context of women's engagement in politics at the local level.

\section{About the Project}

"Gender in Local Politics: Women's Representation at the Local Level" (109k182) is a TUBITAK funded project that aims to listen the experiences of women in Turkey for understanding how the boundaries of the political sphere, in which women try to survive at the local level, are drawn. It was a two years long research conducted with qualitative and quantitative methodologies under the supervision of Prof. Dilek Cindoglu. With regard to methodology, data collection and conceptual analysis have been done at the same time. During the field work, 120 in-depth interviews have been made with local women politicians in 21 cities (between 3/07/2010-11/08/2011). In addition to that, a survey was conducted with 678 male politicians in 11 municipalities in order to understand how male politicians perceive the issues that are pointed out by women.

One of the motivations behind conducting this research is the fact that in most of the states woman's participation in politics at the local level is higher than at the national level (Alkan, 2009: 31). These indicators affirm the general assumption that traditional gender roles situate women usually within the confines of local politics because these roles that are associated with the private sphere, such as caring, cleaning, administration of the household, corresponds to the responsibilities held in local politics. Environmental planning of public parks and gardens, cleaning projects, organization of charity bazaars are the activities that are seen appropriate for a woman as she knows how to "handle" these kinds of activities. At this point what makes this research interesting is that level of women's representation in local politics is lower than the level in national politics in Turkey. When we look at the statistical data the difference becomes clearer. After the general elections held in 2011 women's representation in The Grand National Assembly becomes \% 8.87. When we look at the local level, the result of 2009 local election shows that women's representation at the local level is pretty low. Female mayors elected constitute $\% 9$ of elected mayors; female members of municipal council constitute $\%$ 4.2 and female members of provincial council constitute $\% 3.2$ of elected members respectively. ${ }^{3}$

\section{Anti-Political Experiences}

While analyzing the political nature of experiences of women in local politics in Turkey, this paper uses the data provided by in-depth interviews that were made with women politicians who were elected and/or nominated candidate mayors, elected members of municipal and provincial councils. ${ }^{4}$ Their experiences as told by them would be analyzed in three different dimensions. The first dimension refers to the activities that are narrated as political by the participants. When asked about their political activities most of the female politicians refer to the activities that are essentially associated with the private sphere of life in Arendtian political theory. Among these activities administration of the household, cleaning, gardening and most importantly caring of children in terms of motherhood are the most striking ones. The second dimension refers to participants' own perception about how women make difference in politics. The third one is related with how they are left outside of performing politics in terms of decision making process. They are not able to become a part of decision making process, unless they are let by male politicians. They could not make policy proposals or

\footnotetext{
${ }^{3}$ For the statistical data see http://www.ka-der.org.tr/tr/down/2011_Kadin_Istatistikleri.pdf
}

${ }^{4}$ Translations are mine. 
contribute to already existing system that is defined as dominantly male. ${ }^{5}$ Therefore, they could not "act" and become free in Arendtian sense. Their so-called political experiences are confined within the limits of the private sphere, therefore become anti-political.

First Dimension: From an Arendtian perspective, if you would not become free of necessities of the private sphere, you could never experience freedom in a real sense and you could never become truly political. The private basically includes the household, family relations, economic activities and bodily needs. When we look from this perspective we could observe that women in local politics in Turkey could never become free as they could never leave the private sphere behind to enter into the public that is essentially political. Moreover, for some women politicians the way they administer their household is a proof of how they would be successful in local politics. One participant says:

"In fact, by hosting you today at home I would like to share this. I mean I want you to see my house... this is very important. As we want to make our homes beautiful in every aspect, in material and spiritual way, to the extent that we could... in politics it is the life itself... therefore in social life women's touch would do the same. This is why I strongly believe that women should engage in politics, because women wear different hats. She is the mother, the grandmother, the aunt. All of these roles have different responsibilities; she does her best to fulfill these responsibilities. And imagine an extended family in which you are fulfilling all of these responsibilities. And if we think that women from any political party, who engage in politics and embrace the society with all of these hats... Woman sensitivity is something different." (Ankara, DLP, Retired Teacher, university, 57)

The capacity for the administration of the household is a strong case for them. They strongly believe that this experience gained within the confines of the household would be a good asset in their political life. Another participant explains this potential as follows:

"Woman has a habit stemming from the household. It is related with administration. How can I manage the economy of the household? How can I take care of children? She tries to apply the same logic with the same perspective in the council. How can we organize better? How can we produce services in a healthier way? How can we construct a better team spirit?..." (Mersin, PDP, housewife, secondary school, 36)

Their reference to the activities that belong essentially to the private sphere is not limited to the administration of the household. One of the women politicians argues that men and women are different and firstly women should fulfill their responsibilities at home. Not neglecting their duties at home is something like a magical key that opens the door of success in their political life. The activities done at home are their priority. She says:

"In fact we [women and men] are equals. But we are equals who have different talents and capacities in different areas. Just as a man would not neglect his responsibilities when he engages in politics, a woman also shouldn't ignore hers. I always cook meal. You are capable of doing it somehow, God gave us this talent, or I developed it in time. I prepare the meal; when we got home it is ready! May be this is why my husband supports me a lot. If there were dirty dishes around or laundry was not done when he got home... everything is for us. The machines are there. We are practical, we are talented. Now there are deep-freezers. Consequently, I never neglect my duties." (Trabzon, JDP, retired teacher, university, 54)

This shows that they could never be free of their duties at home and at the same time they are carrying their abilities with regard to these activities to the political sphere. In addition to these duties, it is seen that most of the participants underlies the importance of being a mother. They are proud of saying that a woman's priority is always her children. Caring of the children, having this responsibility, is beyond any kind of human activity. One of the participants puts it as follows:

"Woman is a mother in the first place, my dear. This is all I know. Politics is good, ok, the party, politics... Being mother, God assigns this to us, because we are fertile. Women are mothers in the first place. Her priority is her children... It was like this for me. I don't know if it is like this for other people, but for me, my children come first, because I had to compensate my husband's deficiencies." (Istanbul, RPP, housewife, primary school, 64)

From these quotations it is seen that they could not be free from the activities of the private sphere. They always

${ }^{5}$ For a detailed analysis and critique of male domination in politics see Enloe (2000). 
carry these responsibilities in their minds and reproduce them through their discourse. Because of their nature as fertile beings and capabilities of running a household they could not get rid of the sheer necessity that is inherent in the private sphere. This is why they could never be political and experience freedom in Arendtian sense.

Second Dimension: Mentioned activities and characteristics assigned to women by themselves would bring us the second dimension that is pointed out by this paper. When these women are asked how women contribute to and make difference in politics and political life, the same activities and characteristics are referred. What women think as a contribution to political life is a reproduction and affirmation of the traditional gender roles. Reproduction of these traditional gender roles that are traditionally situated in the private sphere hinders these women going into the public sphere and becoming a part of political experience as acting citizens in Arendtian sense.

When the participants asked about women's capacities about making politics different in different ways, they usually refer to organization and arrangement capacities. One of the participants says:

"Woman's entrance to politics makes it more beautiful, makes it superior. ...I believe that when a woman touches somewhere she makes there more elegant, neat and clean. ... Everywhere she touches is organized and neat. ..." (Mersin, NAP, retired teacher, university, 63)

Within the same lines, this characteristic of being a good organizer who turns the political setting into a "neat" and "clean" environment is associated with the motherhood. One participant from Mugla says:

"Woman is tidy, she is an organizer because of her mother instinct. She is more compassionate and caring. She makes right decisions. ...She is always constructive and positive." (Mugla, RPP, pharmacist, university, 57)

In addition to the activities that are associated with women such as administration of the household, being a mother and cleaning the environment she is in, female characteristics that are underlined by the participants are also interesting. Here are some examples:

\footnotetext{
"...according to my observation woman is more patient... She could be fragile but she is nothing like man. She is fragile because of her nature. Nevertheless, according to me, she is more enthusiastic, more patient, more efficient..." (Izmir, $R P P$, retired teacher, university graduate, 65)
}

"Woman's perspective, her way of paying attention to details, her naivety, sensitivity... when all of these combined you can have a great synthesis. Most of the times I think that this kind of a synthesis should have its repercussions in every sphere..." (Eskisehir, JDP, manager, high school, 44)

It is seen that being "patient", "fragile", "sensitive", "naive" are seen as positive characteristics on the side of the females. These characteristics are seen as a result of their nature. This kind of a perspective is interesting because by seeing these activities and characteristics as a way of making a difference, one is doing nothing more than reproduction and affirmation of traditional gender roles that keep women away from specific spheres and contexts. At this point I should say that underlining the reproduction of traditional gender roles and spacial and contextual separation do not mean despising or ignoring the differences. However, affirmation of this kind of essential separation would harm the equality principle in the public sphere. For Arendt, getting rid of the responsibilities of the private is what makes you equal with others while getting into the public sphere. By emphasizing these differences and accepting that you are assigned to certain duties and spheres would contribute to women's exclusion from the political activity. This would bring us to the last dimension, which is being not able to participate to the decision making process.

Third Dimension: According to Arendt, in order to be political you have to share your words and deeds in the public sphere, which is based on the principles of plurality and equality. As it is mentioned before plurality means the plurality of perspectives and equality means equality of political ranking as acting and participating citizens. When it comes to the experiences of women in local politics in Turkey, male domination of the political sphere becomes an issue. As Bari (2005: 4) suggests women's political participation is obstructed by the male domination of politics and political parties. At the local level, the situation is the same. Women do not take powerful positions. Alkan (2009: 33) quotes "the number of women increases as the power of post decreases." Presenting women as candidates during election time is seen as a mean to contribute political parties' image in the eyes of the public. About this point, the participants say the following:

"The behavior of men is changeable. At the beginning, during the election period, they behave us as if we are flowers. Then it is over. Men are always standing in the forefront. The politics is done at the head office. Local politics takes a back seat." (Adana, RPP, tradeswoman, university graduate, 44) 
"When it comes to be a candidate he sees me appropriate to the position, but when it comes to comment on something, to bring forward your argument he wants you to stop there as you could say something that could disturb him. His position could be threatened; you could be a threat to him. ..." The man does not know how to share. He has the control. ..." (Istanbul, NAP, architect, university graduate, 43)

When it comes to decision making it is men's job to decide on policies. Women are excluded. Therefore, they are not seen as equals and they could not present their perspectives. In a nut shell, they could never be free and political in Arendtian sense. They are not a part of the public sphere as they could not contribute to its constitution. Two of the participants share their experience as follows:

"...The woman is working, taking place in the organization, going to home meetings. But there is no woman as an authority in decision making process and in execution. The woman could not take a step. She could stand back. " (Ankara, JDP, University graduate, reporter, 29)

"Women could not engage in politics alone in our district yet. ... we could not act independently from the mayor and the head of district. I couldn't. I mean I couldn't at first. In accordance with their... I couldn't work as an individual." (Hatay, $J D P$, retired civil servant, high school, 56)

Some thinks that if there was no quota for women in party programmes there would be no place for women in politics. A participant from Black Sea region makes her point as follows:

"If quota was not compulsory these men would never take us to anywhere. ...Because decision makers are all men. They do not let women." (Trabzon, JDP, retired teacher, university, 54)

All in all, these are all cases that show male dominance not just in politics at the national level but also at the local level. Women do not just feel under-represented. From time to time, they also feel that they are used as an image for the prestige of the party and they could never be a part of policy making processes. They are not given important responsibilities; they could not act freely unless they got the approval of male politicians. From time to time they are seen as a threat and constantly reminded of "the fact" that politics is dominated by men and women should stand back. Their voices are not heard. As they could not share their ideas through action and speech, they also become deprived of reality. With regard to this, Arendt would say that even though they are visible, they could not appear within the public sphere.

\section{Conclusion}

Some would argue that Arendt is not the best choice for analyzing the political nature of women's experiences in local politics. This criticism is understandable to a certain extent, because Arendt's insistence on keeping the distinction between the public and the private stemming from political experience of the Greek city state renders her concept of the political limited and exclusivist. However, her original insights about how an individual could become an active citizen in the public sphere through acting and speaking worth to mention. Her insights about performing political action could provide a rich source for the analysis of contemporary political experience. Using the theoretical framework Arendt provides, this paper tries to make an analysis of experiences of women in local politics in Turkey. As a result of this analysis, it is seen that women politicians at the local level in Turkey have anti-political experiences, because, basically, they could not act, experience freedom and reality, and become a constituting actor of the public sphere in Arentian sense.

\section{Acknowledgements}

The ideas and the arguments about the concept of the political in Arendt were presented as a part of my Ph.D. Dissertation, "Exploring the Possibilities for the Social and the Political in the Public-Private Distinction in Arendt" (September 2011).

\section{References}

Alkan, A. (2009). Gendered Structures of Local Politics in Turkey. Digest of Middle East Studiest, 18 (1), 31-56.

Arendt, H. (1958). The Human Condition. Chicago: University of Chicago Press. 
Arendt, H. (1966). The Origins of Totalitarianism. New York: Harcourt, Brace \& World.

Arendt, H. (1976). Eichmann in Jerusalem: A Report On the Banality of Evil. New York: Penguin Books.

Arendt, H. (1993). "What is Freedom?", in Between Past and Future. New York: Viking Press: 143-171.

Arendt, H. (2005). The Promise of Politics. New York: Schocken Books.

Bari, F. (2005). Women's political Participation: Issues and Challenges. paper presented in Expert Group Meeting of United Nations Division for the Advancement of Women (DAW) named Enhancing Participation of Women Development through an Enabling Environment for Achieveing Gender Equality and the Advancement of Women, Bangkok, Thailand, 8-11 November 2005-10-29. Retrieved from http://www.un.org/womenwatch/daw/egm/enabling-environment2005/docs/EGM-WPD-EE-2005-EP.12\%20 \%20draft\%20F.pdf

Cindoglu, D. (2011). Gender in Local Politics: The Issue of Women's representation at Local Level, research project funded by The Scientific and Technological Research Council of Turkey (TUBITAK). Retrieved from http://uvt.ulakbim.gov.tr/uvt/index.php ?cwid=9\&vtadi=TPRJ\&ano=136058 172bc1d42d8fcbaad58ef69f156ef0c1

Dossa, S. (1989). The Public Realm and the Public Self: The Political Theory of Hannah Arendt. Waterloo, Ontorio: Wilfred Laurier University Press.

Enloe, C. (2000).Bananas Beaches and Bases. California: University of California Press.

Habermas, J. (1977). Hannah Arendt's Communications Concept of Power. Social Research, 44, 3-24.

Heller, A. (1991). The Concept of the Political Revisited. In David Held, ed., Political Theory Today (pp. 330-343). Oxford: Polity.

Honig, B. (1995). Toward an Agonistic Feminism: Hannah Arendt and the Politics of Identity. In Bonnie Honig ed., Feminist Interpretations of Hannah Arendt (pp. 135-166). Pennsylvania: The Pennsylvania State University Press.

Pitkin, H. F. (1998). The Attack of the Blob: Hannah Arendt's Concept of the Social. Chicago: The University of Chicago Press.

Zaretsky, E. (1997). Hannah Arendt and the Meaning of Public/Private Distinction. In Craig Calhoun and John McGowan eds., Hannah Arendt and the Meaning of Politics (pp. 207-231). Minneapolis: University of Minnesota Press. 